\title{
25. PALEOMAGNETIC ESTIMATE OF EMPLACEMENT MECHANISMS OF DEEP BASALTIC VOLCANICLASTIC ROCKS IN THE SUMISU RIFT, IZU-BONIN ARC ${ }^{1}$
}

\author{
Masato Koyama, ${ }^{2}$ Stanley M. Cisowski, ${ }^{3}$ and James B. Gill ${ }^{4}$
}

\begin{abstract}
A paleomagnetic study was made on the highly vesiculated basaltic tuff breccia (the basaltic mousse) drilled by Ocean Drilling Program Leg 126 from the Izu-Bonin backarc, Sumisu Rift, to estimate the mode of its emplacement. Thirty-four 10- $\mathrm{cm}^{3}$ minicore samples were collected from almost all the horizons of the basaltic mousse. Stepwise thermal and alternating-field demagnetization experiments show that the natural remanent magnetizations of many samples are mainly composed of a single stable component. Although remanence inclinations are not expected to be disturbed by rotary drilling, the measured inclinations of remanence show a random directional distribution as a whole. The remanence inclinations, however, show directional consistency on a smaller scale. High-density sampling and measurements from a limited interval of drilled cores, and the measurement of small disks cut from a single minicore sample show that there is directional consistency over several centimeters. Strong and stable remanent magnetization, the existence of remanence direction consistency, and the fresh lithology of the samples suggest the thermal origin of remanence. Combining the paleomagnetic results with other geological, petrographical, and paleontological characters, the Hole 791B basaltic mousse can be interpreted as a subaqueous explosion breccia produced by deep-sea pyroclastic fountaining.
\end{abstract}

\section{INTRODUCTION}

Ocean Drilling Program(ODP) Leg 126 drilled five holes (Holes 790A to 790C, 791A, and 791B) in a backarc rift (Sumisu Rift; Fig. 1). Of these, Holes $790 \mathrm{C}$ and $791 \mathrm{~B}$ reached acoustic basement, and a sequence of basaltic breccias and associated lava flows was recovered from the basement. In Hole $791 \mathrm{~B}$, highly vesiculated (35\%-50\% porosity) basaltic breccia, which we called "basaltic mousse" was recovered between 980 and 1115 mbsf (Taylor, Fujioka, et al., 1990; Gill et al., 1990).

The basaltic mousse is composed of a well-indurated mixture of scoriaceous lithic clasts of $\sim 6$-cm diameter within a highly vesiculated glassy lapilli tuff matrix. The mixture is characterized by massive lithology and homogeneous petrography, and shows no significant change vertically. Evidence of reworking or resedimentation, such as grading, lamination, or intercalated hemipelagic sediments, is absent. Lithic clasts have a microcrystalline, tachylitic groundmass, and a few large clasts have quenched rims. Plastically deformed glass can be seen in the matrix of some samples microscopically. Details of the stratigraphy, lithology, petrography, and geochemistry of this deposit are described by Taylor, Fujioka, et al. (1990) and Gill et al. (1990, this volume).

According to Taylor, Fujioka, et al. (1990) and Gill et al. (1990), the age of the basaltic mousse was estimated to be late Pliocene to early Pleistocene, from biostratigraphic studies of the sediments immediately overlying the volcanic rocks. The sediments also yielded benthic foraminifers from the lower bathyal paleodepths. On board paleomagnetic results showed a random distribution of remanence inclinations for the mousse samples. The chemical composition of the basaltic mousse is consistent with its backarc basin origin. Based on all these results, Gill et al. (1990) estimated that the Hole 791B basaltic mousse was produced by an explosive eruption in a lower bathyal backarc rift basin at 1800 2500 meters below sea level (mbsl) depth.

Explosive eruptions can exist only when the pressure on the medium into which the eruption occurs is less than the pressure in the

'Taylor, B., Fujioka, K., et al., 1992. Proc. ODP, Sci. Results, 126: College Station, TX (Ocean Drilling Program).

${ }^{2}$ Faculty of Education, Shizuoka University, 836 Oya, Shizuoka 422, Japan.

${ }^{3}$ Department of Geological Sciences, University of California at Santa Barbara, Santa Barbara, CA 93106, U.S.A.

${ }^{4}$ Department of Earth Sciences, University of California at Santa Cruz, Santa Cruz, CA 95064, U.S.A. eruptive magma. This restricts explosivity to eruptions in subaerial or subaqueous environments shallower than a critical depth (e.g., Fisher, 1984; Fisher and Schmincke, 1984). This depth, which is called the pressure compensation level (PCL), was estimated to be at most $500 \mathrm{~m}$ for the eruption of tholeiitic basaltic magmas (Fisher, 1984). This assertion seems to be discordant with the existence of an explosive volcanism at the paleodepth estimated by Gill et al. (1990). Gill et al. (1990) attributed this abnormal explosivity of the basaltic mousse to its high water content (about $1.3 \%$ by weight). Paleomagnetism is a useful tool for estimating the emplacement mechanisms of volcaniclastic rocks, because the directional consistency and relative intensity are sensitive to the thermal histories of measured materials. Several paleomagnetic studies have attempted to determine the mode of emplacement of various volcaniclastic materials (e.g., Aramaki and Akimoto, 1957; Suzuki, 1962; Napoleone and Yokoyama, 1970; Chadwick, 1971; Kato et al., 1971; Yamazaki et al., 1973; Hoblitt and Kellogg, 1979; Kent et al., 1981; Zlotnicki et al., 1984; McClelland and Druitt, 1989). In this paper, we present a detailed description of paleomagnetic results of the Hole 791B basaltic mousse and discuss the emplacement mechanisms based on the paleomagnetic data and other geological and petrographic results.

\section{SAMPLES AND MEASUREMENT}

All the Hole 791B samples were drilled using an rotary core barrel (RCB), and about $15 \%$ recovery was achieved. Thirty-four $10-\mathrm{cm}^{3}$ minicore specimens were collected from almost all the horizons of the basaltic mousse (Table 1). Of these, six samples were collected from large lithic clasts, and the rest from intervals representing mixtures of lithic clasts and matrix. Most of the samples were fresh, containing fresh glass shards and phenocrysts of olivine and plagioclase with a small amount of secondary smectite in vesicles. Only one sample, from the basal horizon of the basaltic mousse (Sample 126-791B-76R-1, 46-48 cm), is moderately altered, and it includes pseudomorphed olivine phenocrysts and vesicles filled with secondary minerals. The lithic clasts and the matrix are highly vesicular and include no blocky fragments with flat fracture surfaces. Because of the large number of vesicles, it is difficult to define visually boundaries of cooling or deposition units within the mousse matrix.

The samples were measured using a fully automatic spinner (FAS) magnetometer with a built-in AF demagnetizer (Taylor, Fujioka, et al., 1990, pp. 13-42). Fifteen specimens were subjected to stepwise 


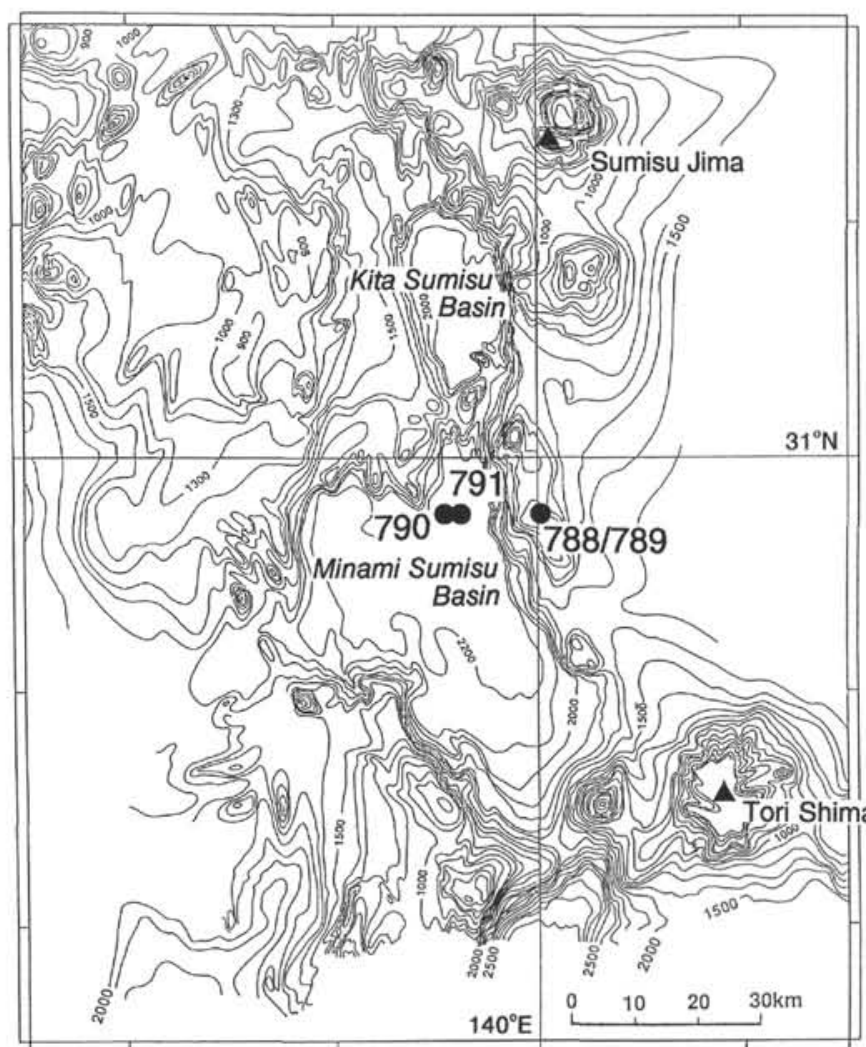

Figure 1. Location map of Leg 126 drill sites in the Izu-Bonin Arc high (Sites 788 and 789) and backarc rift (Sites 790 and 791). The volcanic arc extends from Sumisu Jima through Sites $788 / 789$ to Tori Shima. The Sumisu Rift is composed of the Kita and Minami Sumisu basins. The bathymetric map is from Murakami (1988).

thermal demagnetization (up to $600^{\circ} \mathrm{C}$ ), and 4 to $\mathrm{AF}$ (up to $50 \mathrm{mT}$ ) demagnetization. Thermal demagnetization was performed with the on-board Schonstedt TSD-1 thermal demagnetizer. In addition to these samples, seven minicores were cut into three or four small disks (about $3 \mathrm{~cm}^{3}$ ), and each disk was measured to evaluate the homogeneity of remanence direction within the $10-\mathrm{cm}^{3}$ minicore specimens.

\section{RESULTS}

Typical examples of changes in remanence direction and intensity during stepwise demagnetization are shown in Figures $2 \mathrm{~A}, 2 \mathrm{~B}$, and 2C. Magnetic properties of measured specimens are summarized in Table 1. The intensities of natural remanent magnetization (NRM) of the basaltic mousse specimens range from 60 to $18,000 \mathrm{~mA} / \mathrm{m}$. The samples, including $>50 \%$ lithic clasts, have higher remanence intensities $(5,000$ to $18,000 \mathrm{~mA} / \mathrm{m})$ than those with $<50 \%$ clasts (Table 1 and Fig. 3). In most of the specimens, $90 \%$ of remanence was thermally demagnetized between $300^{\circ}$ and $550^{\circ} \mathrm{C}$ (Fig. 2A). The remanence directions were generally stable and changed $<5^{\circ}$ with the stepwise thermal and AF demagnetizations (Figs. 2A and 2B), with no correlation to clast content. The median demagnetizing field (MDF) and the mean blocking temperature (MBT) generally range from 30 to $46 \mathrm{mT}$ and from $300^{\circ}$ to $440^{\circ}$, respectively. One exception is Sample 126-791B-73R-2, 84-86 cm, which shows a large directional change and the existence of at least two remanence components (Fig. 2C).

Figure 4 is a histogram of the remanence inclinations for the mousse samples. Although remanence inclinations are not expected to be disturbed by rotary drilling, the measured inclinations show completely random distribution, having no dependence on the lithic clast content of each sample.

However, the remanence directions do become consistent on a smaller scale. Figure 5 shows the remanence directions of disk specimens cut from the minicore samples. Many of the disks cut from the same minicore have consistent directions $\left(\alpha_{95}=8^{\circ}-35^{\circ}\right)$, except for Samples 126-791B-66R-1, 103-105 cm, and -67R-1, 42-44 cm, in which the directions of single disks are $>50^{\circ}$ from the direction of the other two disks from the same sample. The directional consistency among the disk specimens cut from the same minicore sample is not always restricted to multiple sampling of the same lithic clast. In Sample 126-791B-64R-1, 59-61 cm, three disks, each of which has a $<10 \%$ clast content (Table 1), show similar remanence directions. In Sample 126-791B-66R-1, 126-128 cm, the upper and lower disks, including different lithic clasts, show similar remanence directions. In Sample 126-791B-66R-1, 132-134 cm, the upper disk has a $<5 \%$ clast content, whereas the other three disks have $50 \%-70 \%$ clast content (Table 1), yet all show similar inclinations. In Sample 126791B-67R-1, $42-44 \mathrm{~cm}$, the middle disk with a $<5 \%$ clast content shows a similar direction to that of the lower disk with a $15 \%$ clast content. These results suggest that there usually is internal consistency of remanence direction for the basaltic mousse on a scale of about $10 \mathrm{~cm}^{3}$, and that the directional consistency also exists between both clasts and matrix within the same minicore specimen.

Figure 6 summarizes the remanence direction and intensity of the 18 samples that were collected from an $\sim 1.5-\mathrm{m}$ interval of the basaltic mousse (from Samples 126-791B-66R-1, 52-54 cm, to -66R-2, 39$41 \mathrm{~cm}$ ), with sampling intervals of 1 to $30 \mathrm{~cm}$ (Table 1). The remanence directions of one $10-\mathrm{cm}^{3}$ minicore and seven $3-\mathrm{cm}^{3}$ disk samples from one core piece about $15 \mathrm{~cm}$ long (126-791B-66R-1, Piece 19) coincide with each other $\left(\alpha_{95}=6.3^{\circ}\right)$, except for the one minicore from the top of the piece (Sample 126-791B-66R-1, 122-124 cm). Of these, Sample 126-791B-66R-1, 125-127 cm, and the upper disk from Sample 126-791B-66R-1, 132-134 cm, have $<5 \%$ lithic clast content, whereas the other samples have $30 \%-70 \%$ clast content (Table 1). This supports the directional consistency between both clasts and matrix within this piece, except for the uppermost part including Sample 126-791B-66R-1, 122-124 cm. In contrast, in other core pieces (126-791B-66R-1, Pieces 15 and 17, and 126-791B-66R-2, Pieces la to $1 \mathrm{c}$ ), there is no consistent remanence directions within the same piece or between lithic clasts and matrix (Fig. 6), except for the four disks from the same minicore sample in 126-791B-66R-2, Piece $1 \mathrm{~b}$.

All these results from detailed sampling on a smaller scale suggest that the size of directional consistency of the basaltic mousse is on the order of several centimeters, which is generally larger than a $10-\mathrm{cm}^{3}$ minicore (2.5-cm diameter), but smaller than the $15-\mathrm{cm}$-long core pieces (6- $\mathrm{cm}$ diameter), and that within the intervals of such directional consistency, both clasts and matrix have similar remanence directions.

\section{DISCUSSION}

As stated in the previous sections, the basaltic mousse is composed of volcanic materials with no evidence of reworking or resedimentation. This strongly suggests that the volcaniclastic fragments were produced in situ. The magnetic properties of the basaltic mousse are generally characterized by strong NRM intensities and by the dominance of a single stable component with high MBT and MDF. The $\mathrm{NRM} / \mathrm{IRMs}$ ratio (after AF demagnetization to $25 \mathrm{mT}$ ) for mousse Sample $126-791 \mathrm{~B}-72 \mathrm{R}-2,3-5 \mathrm{~cm}$, is $1.40 \times 10^{-2}$, which is a value characteristic of igneous rocks that carry a full TRM (Cisowski et al., 1990). The remanence vectors of the basaltic mousse samples show directional consistencies of $\sim 2-15 \mathrm{~cm}$ diameter, although they are coarse-grained volcaniclastics. In the intervals showing consistency of remanence directions, both clasts and matrix seem to have similar directions of remanence. All these results suggest the thermal origin 
Table 1. Summary of horizon, lithology, and paleomagnetic results of the Hole 791B basaltic mousse samples.

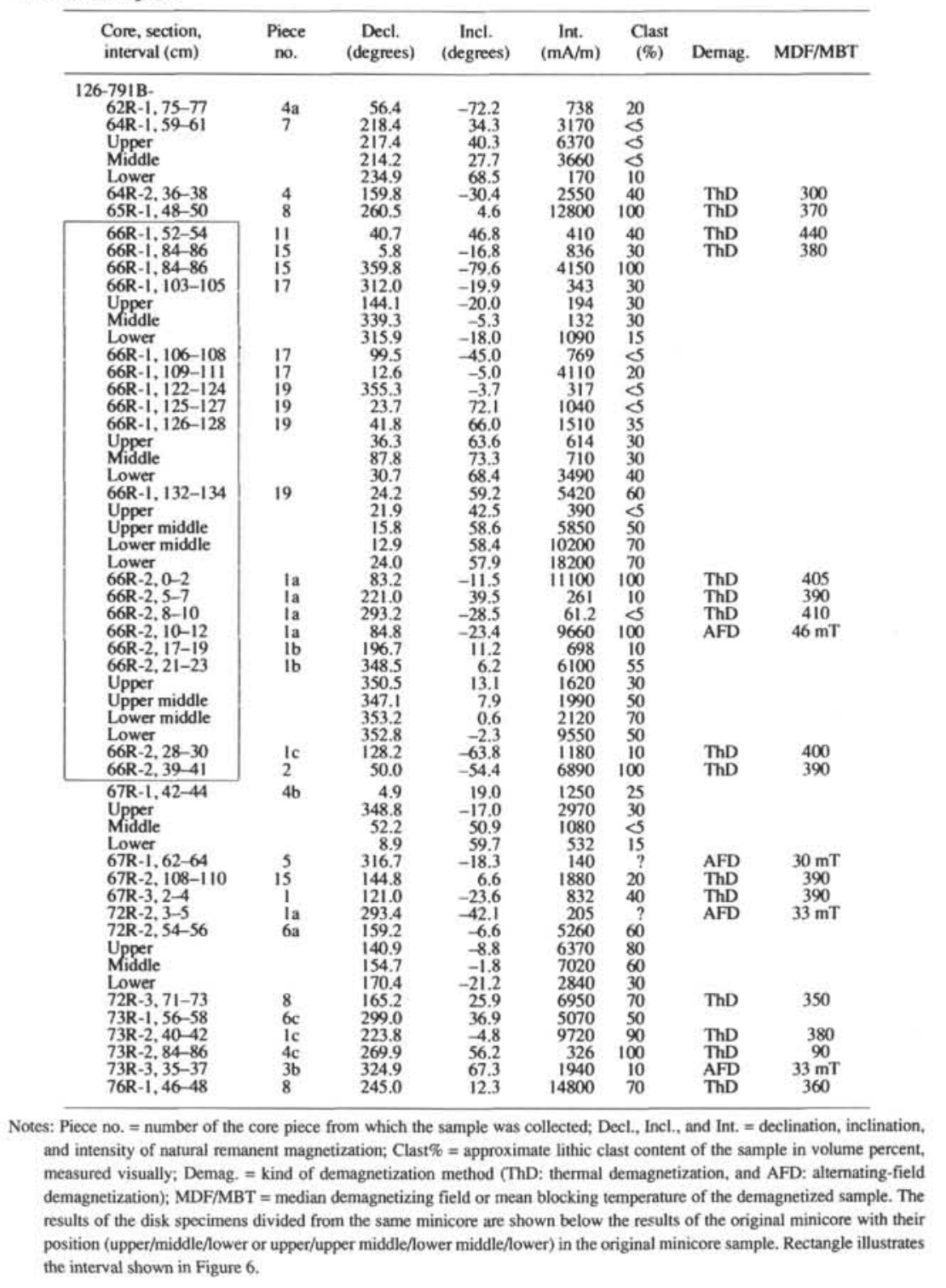

of the remanent magnetization of the basaltic mousse. Thus, directional consistency within a limited interval probably indicates a cooling unit, and the stable remanence direction represents the thermal remanent magnetization (TRM) direction of each cooling unit.

Considering the random distribution of remanence inclinations of the basaltic mousse as a whole, we evaluate two models for its emplacement mechanisms (Fig. 7): one involves deep-sea explosive fountaining of basaltic magma (Fig. 7A); the other involves nonexplosive emplacement of a hyaloclastic lava flow (Fig. 7B). The explosive fountaining model assumes that deep-sea fountaining produces the volcaniclastic fragments of the basaltic mousse. The explosivity of magma is caused by the rapid expansion of dissolved $\mathrm{H}_{2} \mathrm{O}$ in magma, as proposed by Gill et al. (1990). The nonexplosive emplacement model assumes the nonexplosive eruption of the basaltic mousse as hyaloclastic lava flows. The volcaniclastic character of the basaltic mousse is mainly caused by hyaloclastic fragmentation.

The dominance of a single stable component of TRM in most of the samples requires that each cooling unit of the basaltic mousse erupted as volcanic ejecta in a hot state and then settled and amalgamated after rapid cooling in the water column to an ambient tempera- basaltic mousse clasts as illustrated in Figure 8. After formation of a volcaniclastic cone or layer during a previous eruptive episode, new magma with similar chemical composition erupted and incorporated the unconsolidated old scorias, thus producing a mixture of the older lithic clasts and younger matrix. Mixing of the clasts and matrix probably occurred in the vent and fountain, where repeated recircuture (Fig. 7A). Rapid cooling before settling, the frothy appearance of volcaniclastic fragments and the lack of blocky fragments with flat fracture surfaces, the small size of a cooling unit $(\sim 2-15 \mathrm{~cm})$, and the completely random distribution of the remanence direction of each cooling unit, all favor the explosive fountaining model.

How were the lithic clasts of the basaltic mousse made? According to Gill et al. (1990), the clasts are characterized by similar chemical composition to the mousse matrix but by a higher degree of crystallization and alteration. Thus, they probably are accessory fragments that are older than the matrix. The systematic difference of remanence intensities between clasts and matrix (Fig. 3) supports the different origin of them, although the cause of the intensity difference cannot be defined yet. Based on the characteristics of the basaltic mousse stated and discussed above, we propose a model for the origin of the 
A. Sample 126-791B-66R-2, 39-41 cm
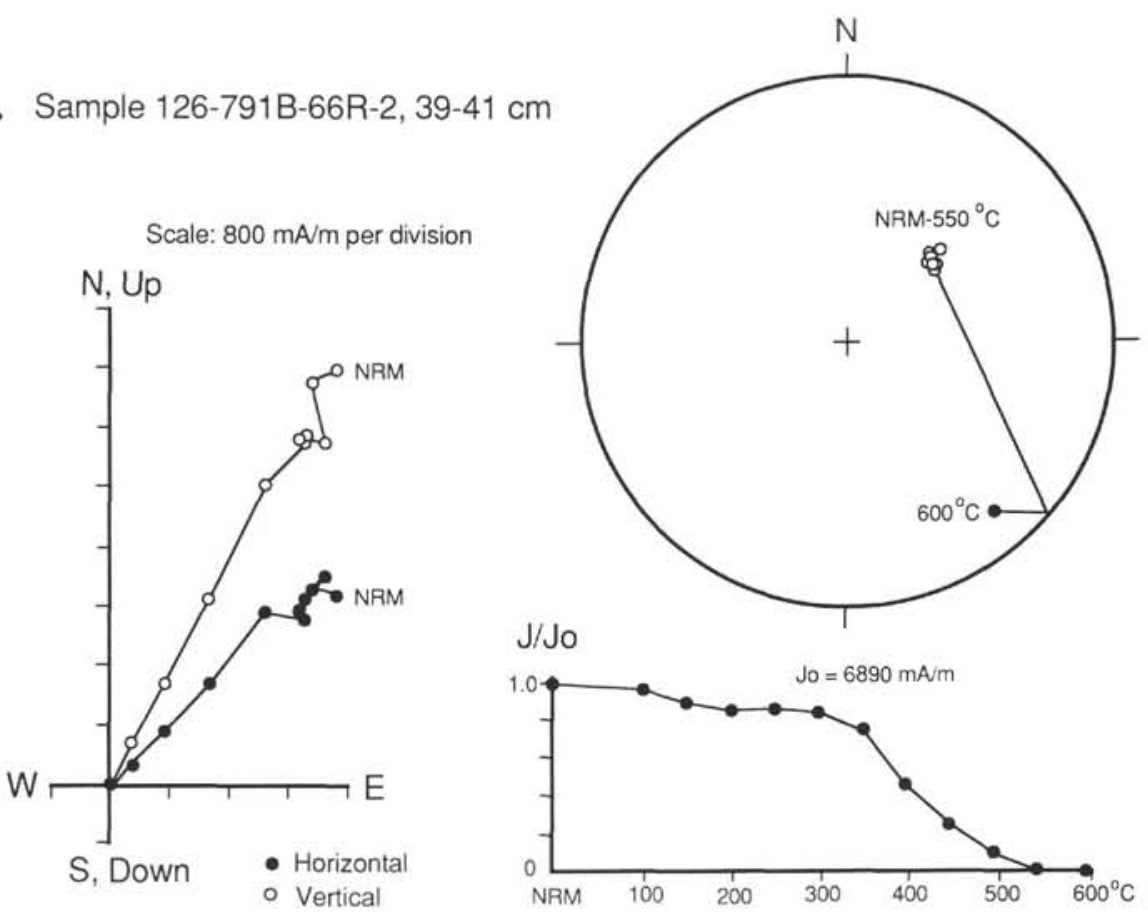

Sample 126-791B-66R-2, 5-7 cm
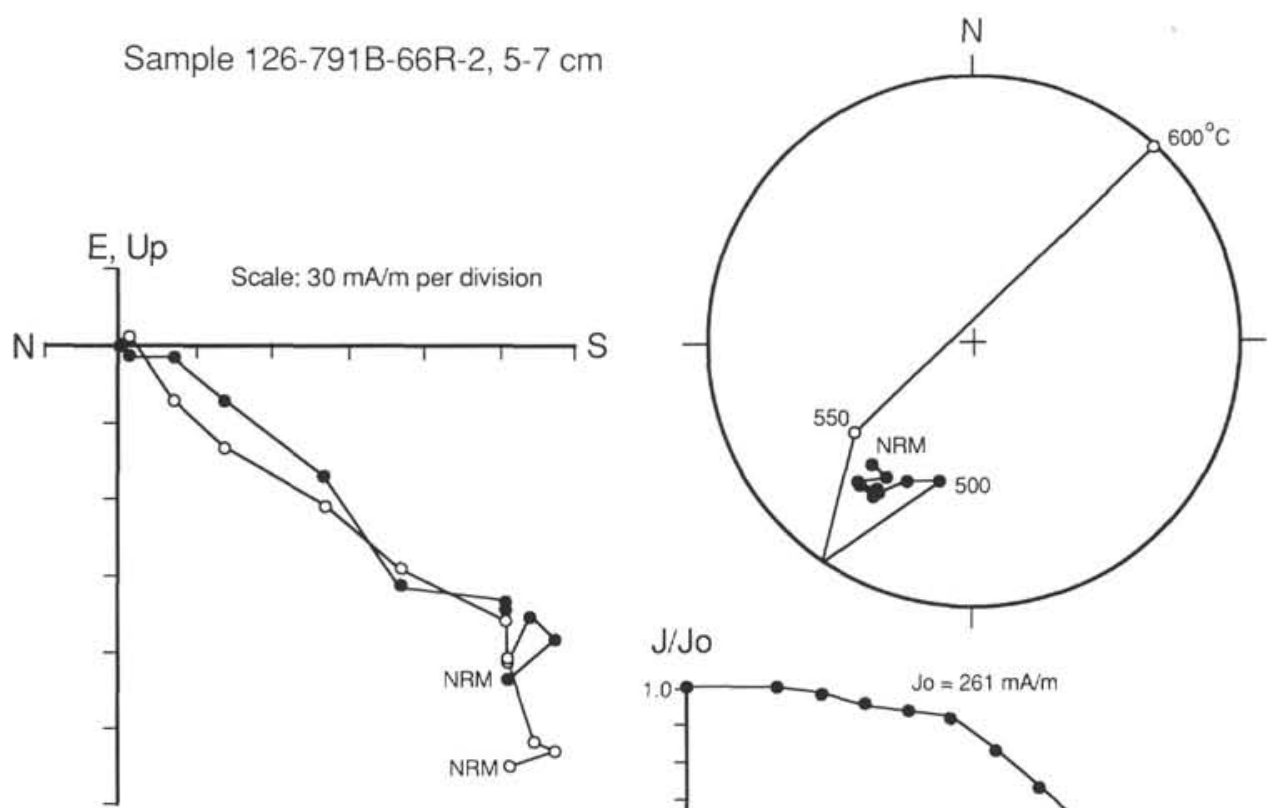

W, Down

- Horizontal

- Vertical

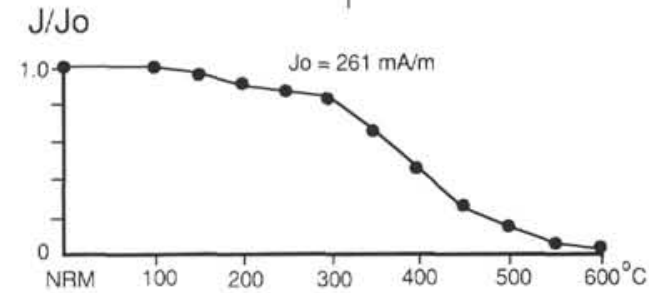

Figure 2. Typical example of change of remanent magnetization vector during stepwise thermal (A and $\mathbf{C})$ and alternating-field (B) demagnetizations. Solid and open circles on equal-area projections are on lower and upper hemispheres, respectively. 
B. Sample 126-791B-66R-2, 21-23 cm

Scale: $1300 \mathrm{~mA} / \mathrm{m}$ per division
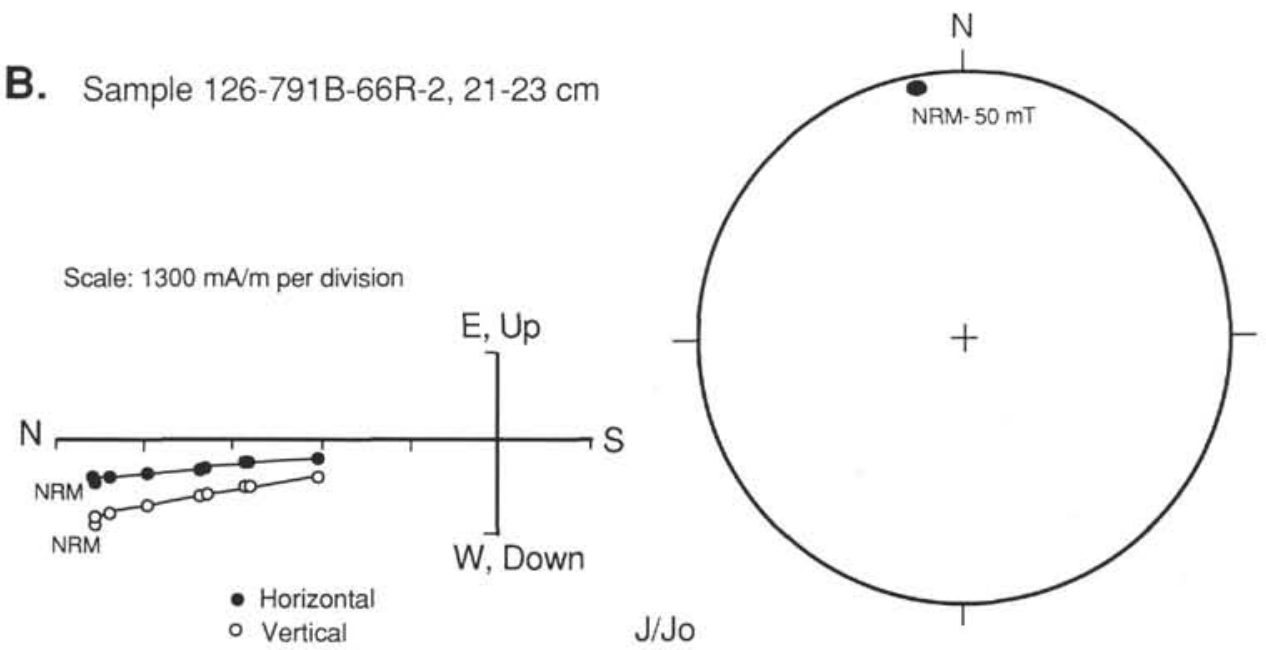

- Vertical

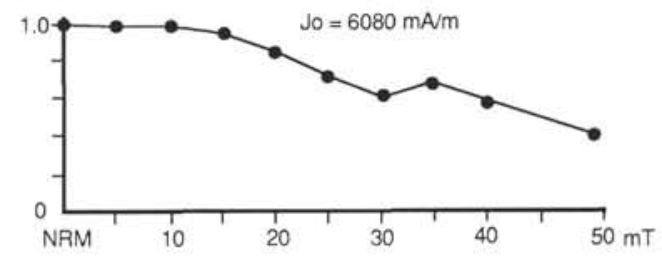

C. Sample 126-791B-73R-2, $84-86 \mathrm{~cm}$

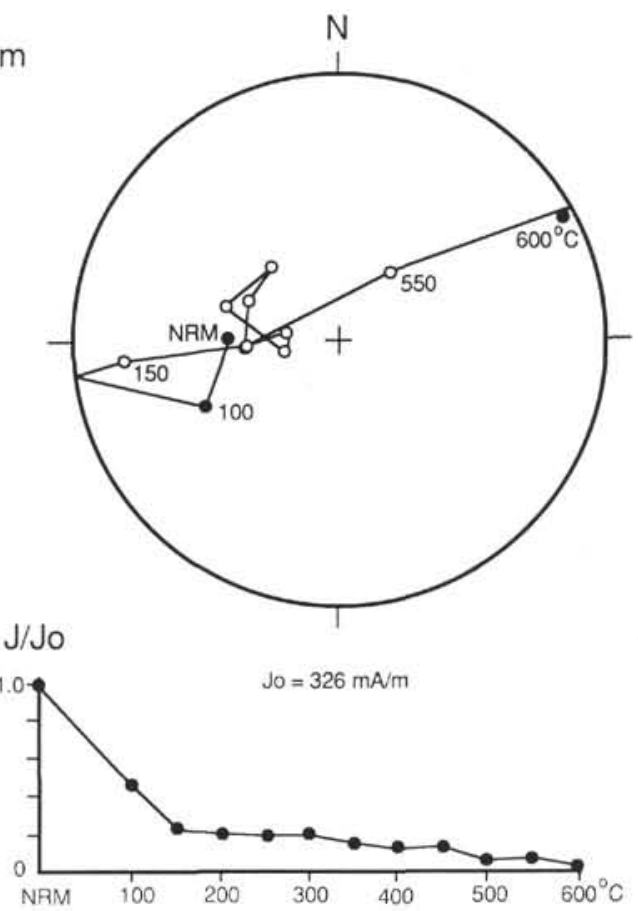

Figure 2 (continued).

lation of volcanic materials is expected to exist. As stated above, some clasts have remanence directions consistent with the adjacent matrix. This can be explained as a result of the reheating of older clasts by the adjacent younger matrix. One pure clast sample having two remanence component directions (Sample 126-791B73R-2, 84-86 cm; Fig. 2C) can be interpreted as an example of incomplete reheating of the clast.

\section{CONCLUSION}

Highly vesiculated basaltic tuff breccia (the basaltic mousse) was drilled and recovered from the Izu-Bonin backarc rift basin. On the basis of geological, petrological, paleontological, and geophysical evidence, Gill et al. (1990) estimated the basaltic mousse to have erupted by explosive fountaining at a depth of $1800-2500 \mathrm{mbsl}$. The 


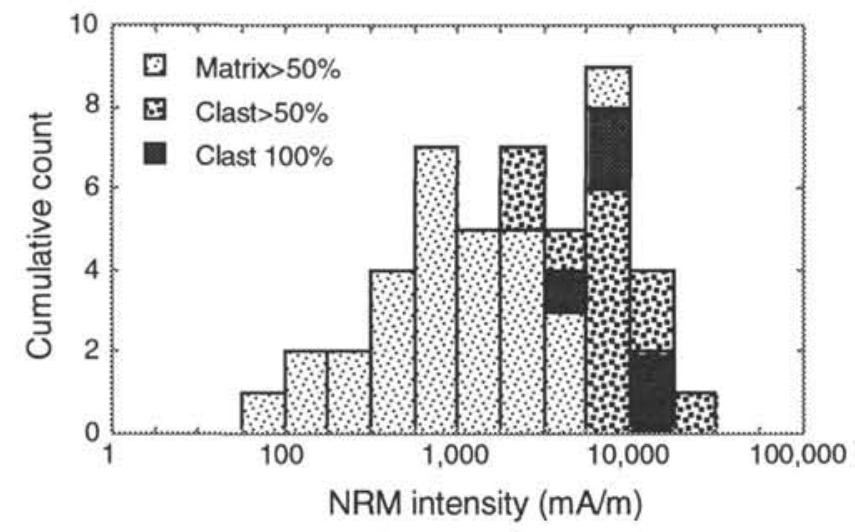

Figure 3. Histogram showing the distribution of NRM intensity of the basaltic mousse samples. Lithic clast content (clast\% by volume) of each sample is shown by patterns.

present paleomagnetic study confirms the thermal origin of remanent magnetization of the basaltic mousse and defines the rather small size $(\sim 2-15 \mathrm{~cm})$ of each cooling unit. These results support the explosive fountaining model for the emplacement mechanism of the basaltic mousse and enable us to reconstruct the details of the eruptive sequence.

\section{ACKNOWLEDGMENTS}

We thank all the on-board scientists, technicians, and JOIDES Resolution crew who supported this study. M. Koyama thanks Miss Y. Matsuo for her help in making thin sections, and is also grateful to Drs. S. Umino and Y. Hayakawa for their discussions and critical comments. We also thank Drs. E. McClelland and S. Aramaki for their critical reviewing the manuscript.

\section{REFERENCES}

Aramaki, S., and Akimoto, S., 1957. Temperature estimation of pyroclastic deposits by natural remanent magnetism. Am. J. Sci., 255:619-627.

Chadwick, R. A., 1971. Paleomagnetic criteria for volcanic breccia emplacement. Geol. Soc. Am. Bull., 82:2285-2294.

Cisowski, S. M., Dunn, J. R., Fuller, M., and Wasilewski, P. J., 1990. NRM:IRM(s) demagnetization plots of intrusive rocks and the origin of their NRM. Tectonophysics, 184:35-54.
Fisher, R. V., 1984. Submarine volcaniclastic rocks. In Kokelaar, B. P., and Howells, M. F. (Eds.), Marginal Basin Geology: Volcanic and Associated Sedimentary Processes in Modern and Ancient Basins. Geol. Soc. Spec. Publ. London, 16:5-28.

Fisher, R. V., and Schmincke, H.-U., 1984. Pyroclastic Rocks: Berlin (Springer-Verlag).

Gill, J., Torssander, P., Lapierre, H., Taylor, R., Kaiho, K., Koyama, M., Kusakabe, M., Aitchison, J., Cisowski, S., Dadey, K., Fujioka, K., Klaus, A., Lovell, M., Marsaglia, K., Pezard, P., Taylor, B., and Tazaki, K., 1990. Explosive deep water basalt in the Sumisu backarc rift. Science, 248:1214-1217.

Hoblitt, R. P., and Kellogg, K. S., 1979. Emplacement temperature of unsorted and unstratified deposits of volcanic rock debris as determined by paleomagnetic techniques. Geol. Soc. Am. Bull., 90:633-642.

Kato, T., Muroi, I., Yamazaki, T., and Abe, M., 1971. Subaqueous pyroclastic flow deposits in the upper Donzurubo Formation, Nijo-san district, Osaka, Japan. J. Geol. Soc. Jpn., 77:193-206.

Kent, D. V., Ninkovich, D., Pescatore, T., and Sparks, S.R.J., 1981. Palaeomagnetic determination of emplacement temperature of Vesuvius AD 79 pyroclastic deposits. Nature, 290:393-396.

McClelland, E. A., and Druitt, T. H., 1989. Palaeomagnetic estimates of emplacement temperatures of pyroclastic deposits on Santorini, Greece. Bull. Volcanol., 51:16-27.

Murakami, F., 1988. Structural framework of the Sumisu Rift, Izu-Ogasawara Arc. Bull. Geol. Soc. Japan, 39:1-21.

Napoleone, G., and Yokoyama, I., 1970. Volcanological and paleomagnetic studies of welded tuff from Sikotu Caldera, Hokkaido. Bull. Volcanol. Soc. Japan, 15:87-95. (in Japanese with English abstract)

Suzuki, T., 1962. Natural remanent magnetism of Shikotsu welded tuff deposits. Geophys. Bull. Hokkaido Univ., 9:1-10. (in Japanese)

Taylor, B., Fujioka, K., et al., 1990. Proc. ODP, Init. Repts., 126: College Station, TX (Ocean Drilling Program).

Yamazaki, T., Kato, I., Muroi, I., and Abe, M., 1973. Textural analysis and flow mechanism of the Donzurubo subaqueous pyroclastic flow deposits. Bull. Volcanol., 37:231-244.

Zlotnicki, J., Pozzi, J. P., Boudon, G., and Moreau, M. G., 1984. A new method for the determination of the setting temperature of pyroclastic deposits (example of Guadeloupe: French West Indies). J. Volcanol. Geotherm. Res., 21:297-312.

Date of initial receipt: 2 January 1991

Date of acceptance: 24 July 1991

Ms 126B-144

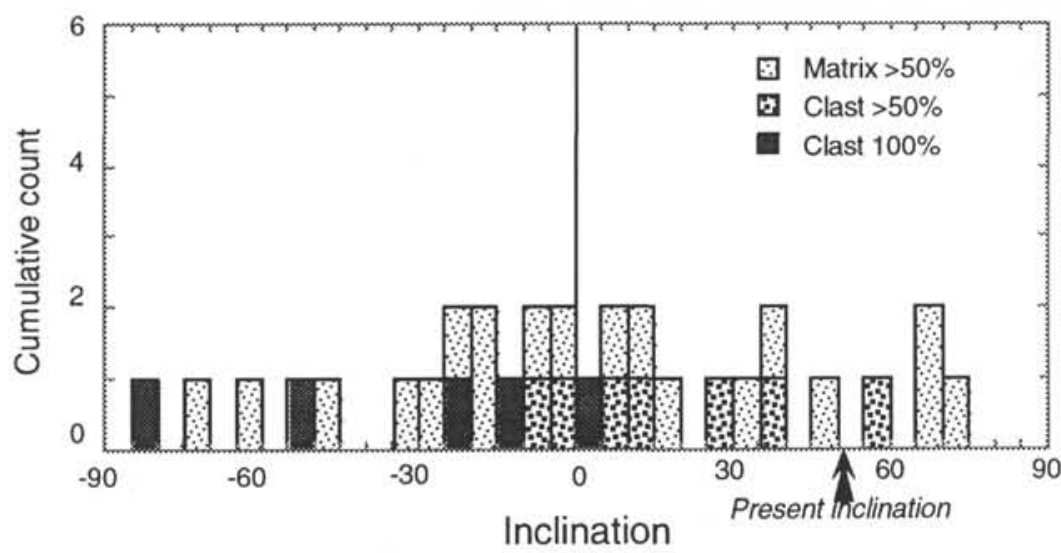

Figure 4. Histogram showing the directional distribution of remanence inclination of the basaltic mousse samples. Lithic clast content (clast\% by volume) of each sample is shown by patterns. 


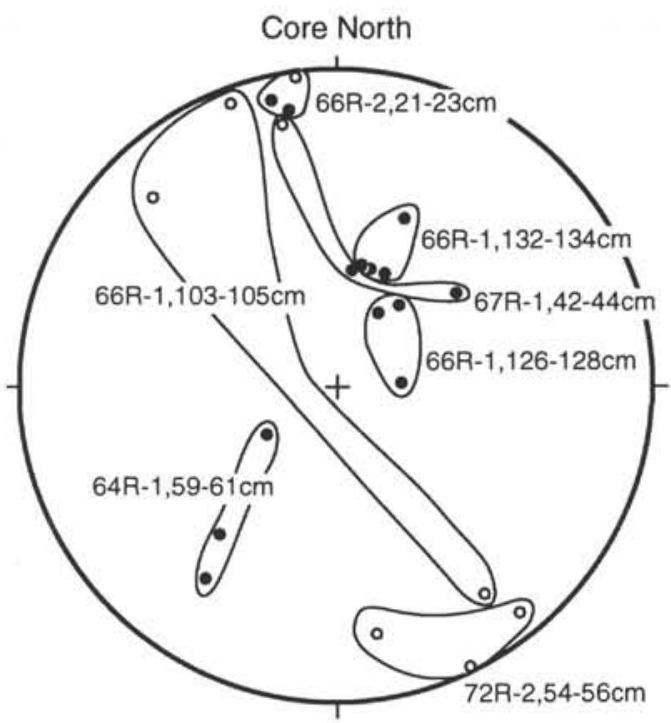

Figure 5. Equal area projection showing remanence directions of small disk specimens taken from the selected minicore samples. Disks from the same minicore are circled with a solid line. Solid and open circles are on lower and upper hemispheres, respectively. 
A.

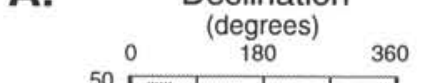

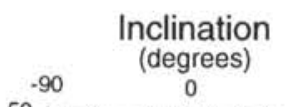
rees)

90
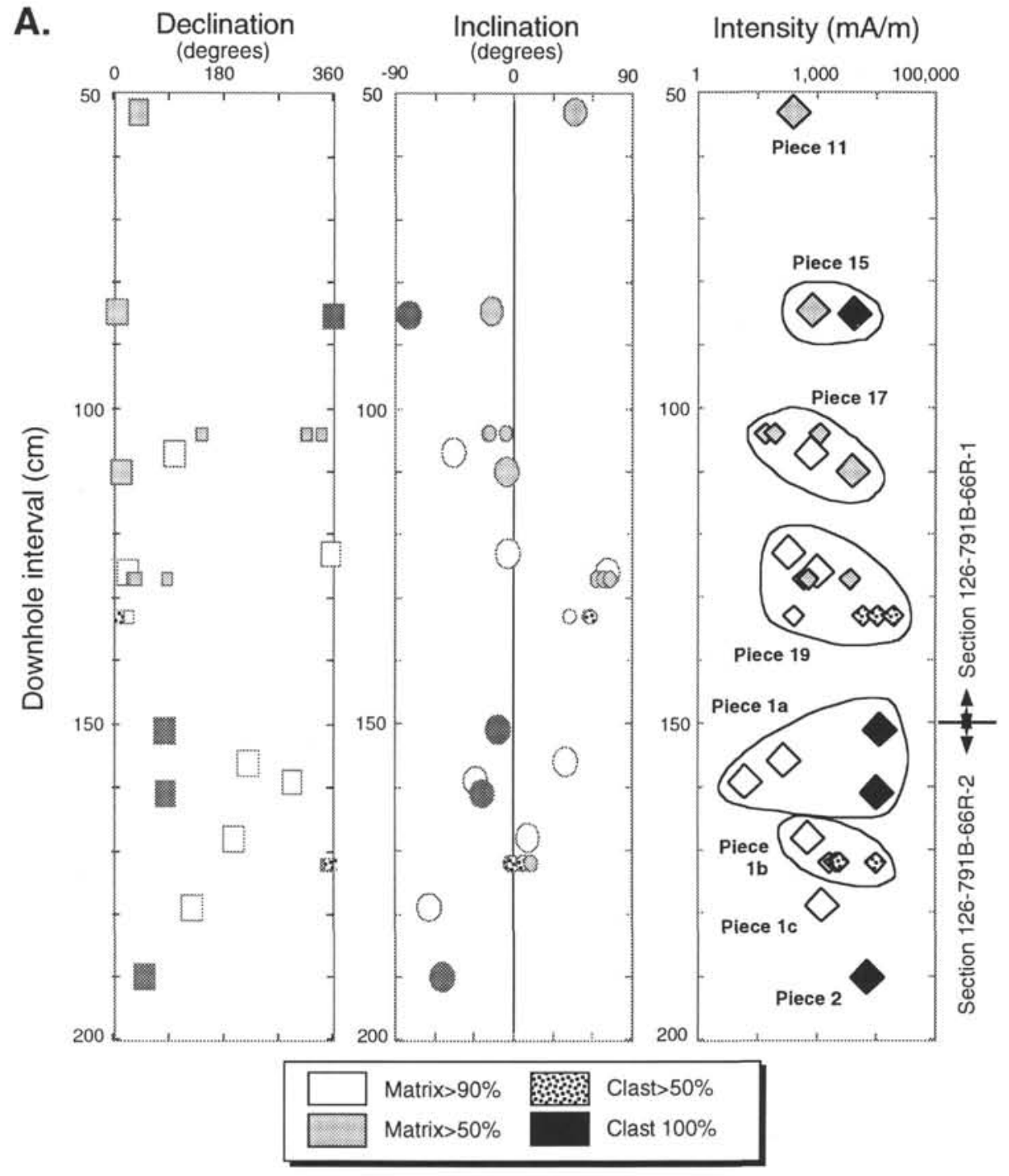

Figure 6. Diagrams showing the directional consistency of remanence of the samples collected from Sections 126-791B-66R-1 and -66R-2. A. Relationship between the downhole interval and remanence declination, inclination, and intensity of each sample. Vertical axis shows the downhole interval from the top of Section 126-791B-66R-1. Square, triangle, and diamond show the declination, inclination, and intensity of samples, respectively. Smaller symbols correspond to the disk specimens taken from minicore samples. Each symbol is filled with the pattern corresponding to the lithic clast content of each sample. The samples collected from the same piece are circled with a solid line in the intensity column. Pieces la-1c may be regarded as a single rigid piece without any drilling rotation, because they are fitted well with each other along their boundaries. B. Equal-area projection showing the remanence directions of the samples belonging to Pieces 15, 17, 19, and 1a-1c. Each symbol shows the identification of piece number. Smaller symbols correspond to the disk specimens taken from minicore samples. Solid and open symbols are on lower and upper hemispheres, respectively. 


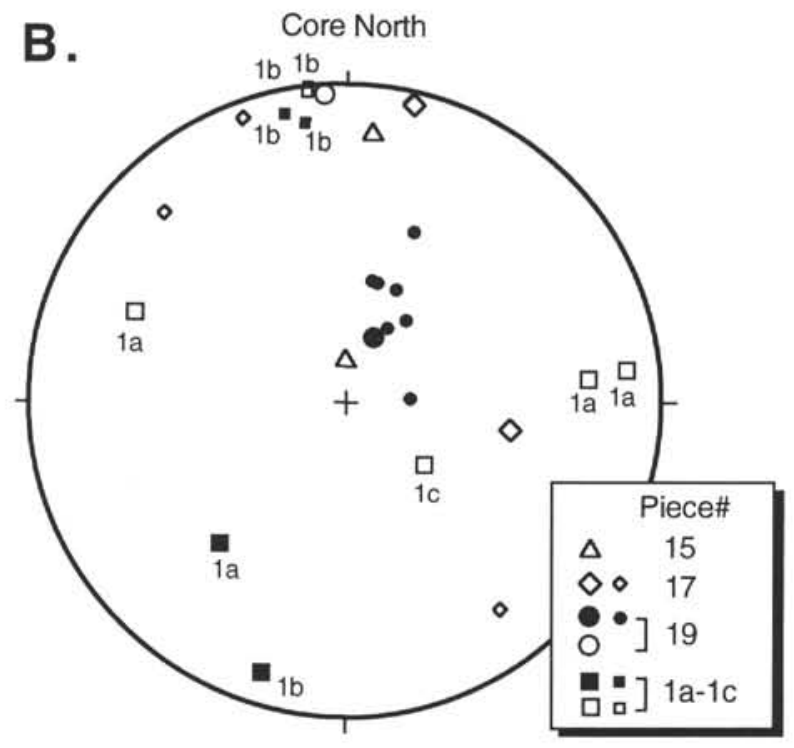

Figure 6 (continued).

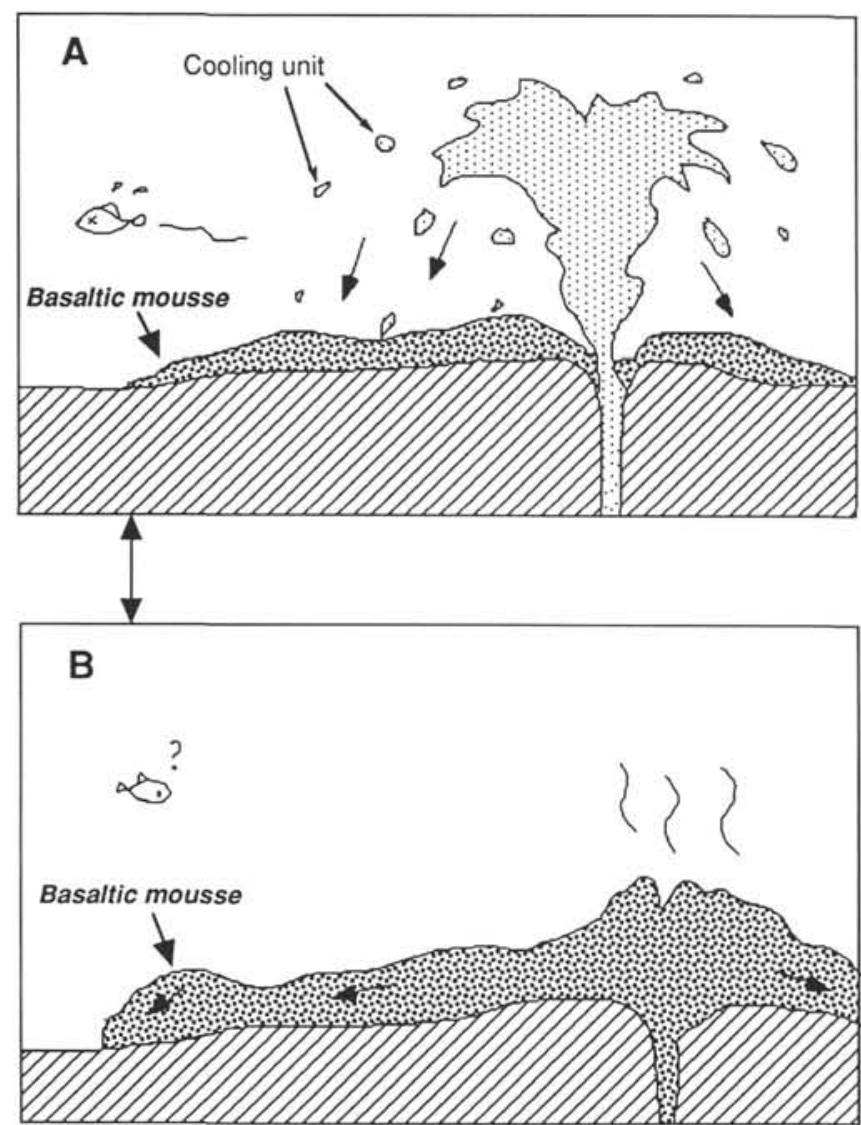

Figure 7. Schematic diagram illustrating two models of the emplacement mechanism of the basaltic mousse in a subaqueous environment. Top and bottom figures show the explosive fountaining model (A) and the nonexplosive emplacement model (B), respectively. See text for further explanations.

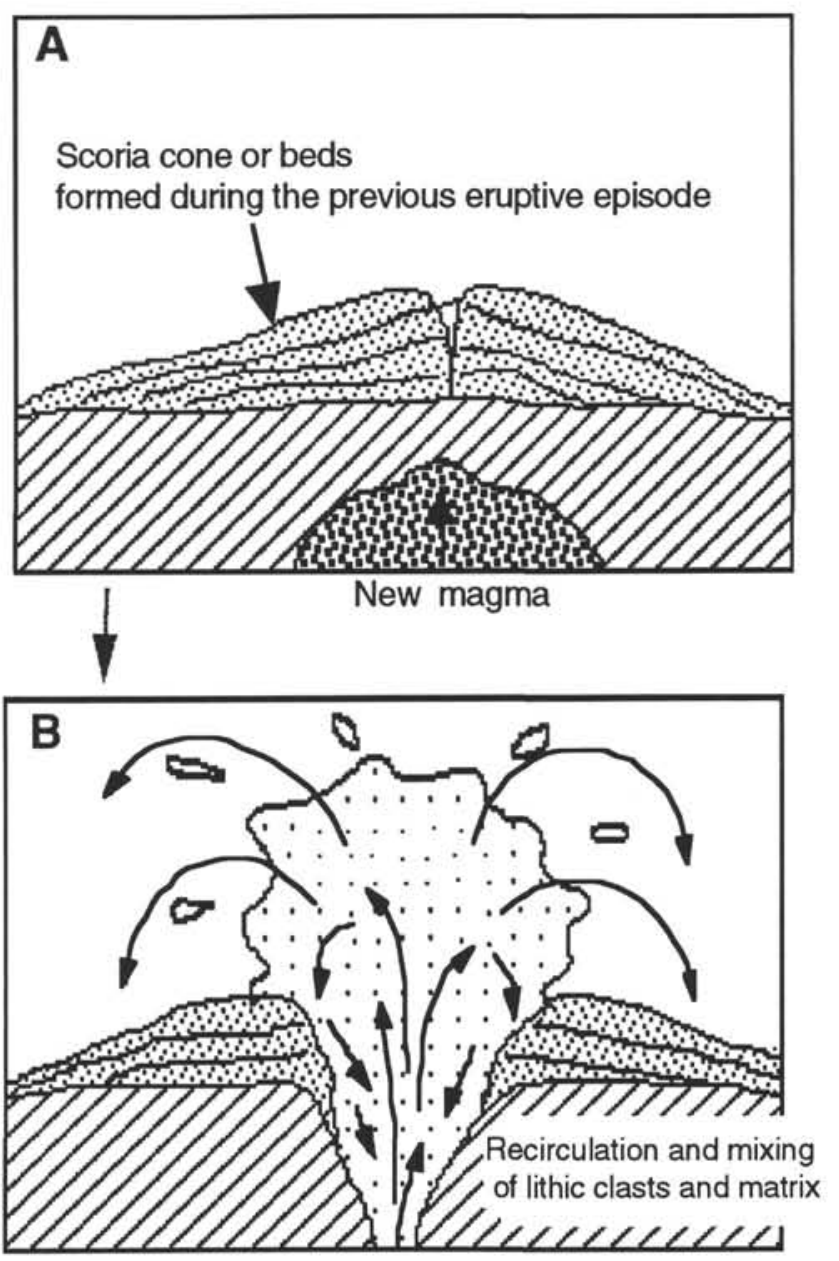

Figure 8. Schematic diagram illustrating the origin of the lithic clasts and matrix of the basaltic mousse. A. A volcaniclastic cone or layer was formed during a previous eruptive episode. B. New magma then erupted and incorporated the unconsolidated old scorias. See text for further explanation. 